\title{
A Curse of Knowledge in Diagnosis of Thalassemia
}

\author{
Fatma Aljasmi, Srdjan Denic, and Abdul-Kader Souid
}

\begin{abstract}
How socioeconomic development affect the diagnosis of thalassemia? Here, we report a couple (husband and wife) from United Arab Emirates (UAE) with microcytic anemia. The parents belong to Arabian tribes with a high prevalence of $\alpha$ - and $\beta$-thalassemia. They wanted to have another (sixth) child and their blood counts were investigated before in vitro fertilization. The parents and five children had standard blood tests (complete blood and reticulocyte cell counts, serum ferritin, and hemoglobin analysis) followed by genetic investigations of hemoglobin- $\alpha$ locus 1 and 2 . In addition, the parents had a genetic investigation of hemoglobin- $\beta$ locus for 22 common variants. The parents were found to have no abnormality in hemoglobin- $\beta$ locus. They had two pathogenic $\alpha$-globin gene variants: one rare variant in the 3' prime untranslated region of $H B A 2 \quad(c . * 92 \mathrm{~A}>\mathrm{G}$; rs63750067) and one common deletion in $H B A 2\left(-\alpha^{3.7}\right)$. There were four distinct genotypes: $-\alpha^{3.7}$ homozygote (mother), c. $* 92 \mathrm{~A}>\mathrm{G}$ heterozygote (father), double heterozygotes (four children), and $-\alpha^{3.7}$ heterozygote (one child). The couple was cleared for the in vitro fertilization. In contrast to 'standard' approach, the genetic test for thalassemia is controversial. The findings in this family are discussed in the context of recent epidemiologic and genetic studies in the local population. It was concluded that the rapid development in the UAE was accompanied by acquisition of new information about thalassemia which, paradoxically, increased diagnostic uncertainties in the setting of premarital guidance.

Index Terms - Decision Analysis; Differential Diagnosis; Information Seeking Behavior; Referral and Consultation; Socioeconomic Factors.
\end{abstract}

\section{INTRODUCTION}

Highlight Socioeconomic development improves the health and education of people. In the UAE, oil riches have enabled a rapid transformation of the tribal population into a prosperous nation $[1,2]$. At the same time, the progress has exposed hidden medical problems. For example, half of apparently healthy young Emiratis have abnormal blood count; and $27 \%$ of the women and $3 \%$ of the men are anemic due to high prevalence of $\alpha$ - and $\beta$-thalassemia and iron deficiency [3]. The burden of genetic diseases in the country is further increased by the high rate of consanguineous marriages [4]. The population is aware of the hereditary nature of some forms of anemia, premarital screening for hemoglobinopathies is mandatory, and genetic testing is available. As a result, the incidence of diseases such as thalassemia major and sickle cell anemia has been

Published on March 25, 2020

Fatma Aljasmi, Department of Genetics and Genomics, United Arab Emirates University, UAE. (e-mail: aljasmif@uaeu.ac.ae),

Srdjan Denic, Department of Medicine, United Arab Emirates University, UAE. (e-mail: s.denic@uaeu.ac.ae)

Abdul-Kader Souid, Department of Pediatrics at the College of Medicine and Health Sciences, United Arab Emirates University, UAE.

(e-mail: asouid@uaeu.ac.ae) reduced [5]. Here, we analyzed the phenotype, genotype, and the risk of thalassemia in one modern-day Emirati family with anemia.

\section{CAse Presentation}

The 44- and 43-year-old Emirati husband and wife were referred for genetic counseling before in vitro fertilization because of microcytic anemia. They were healthy, biologically related as first cousin, well educated, and already had five healthy children conceived naturally. The couple was unable to have another (sixth) child and sought help in a local fertility center. Their physician was concern about the risk of anemia in future offspring and referred the couple to hematologist. The physical examinations of the husband and wife were normal.

Table 1 shows the results of initial laboratory evaluation (complete blood cell and reticulocyte counts, serum ferritin, and hemoglobin analysis by high-pressure liquid chromatography) of all seven family members. The mother was iron deficient and iron treatment was commenced.

Investigation of hemoglobin- $\beta$ locus ( $H B B$, MIM\#141900) gene for 22 variants common in India and the Middle East was performed in the parents by Vienna Lab Diagnostics GmbH (Vienna, Austria), and results were normal. Subsequently, full sequencing and deletion/duplication of hemoglobin- $\alpha$ locus 1 (HBA1, MIM\#141800) and hemoglobin- $\alpha$ locus 2 (HBA2, MIM\#141850) genes were performed in all family members by Centogene AG (Rostock, Germany), and results are shown in Table 1. There were two pathogenic variants: one rare (NM_000517.6(HBA2):c.*92A $>\mathrm{G} ;$ rs63750067) and one common (a dinucleotide deletion in -alpha3.7 $\left[-\alpha^{3.7}\right]$ allele\#362635: NM_000517.4(HBA2):c.[-2_-3delAC;alpha3.7]; variation\#375757) (6-10). There were four distinct genotypes: $-\alpha^{3.7}$ homozygote (mother), NM_000517.6(HBA2):c.*92A $>\mathrm{G}$ heterozygote (father), double heterozygotes (four children), and $-\alpha^{3.7}$ heterozygote (one child). The couple's diagnosis was $\alpha$-thalassemia trait that is not contraindication for in vitro fertilization.

\section{DISCUSSION}

In the analysis of the diagnostic process, three issues were identified:

\section{A. Who was anemic?}

All seven family members were anemic, using reference standards for people of European ancestry (Table 1). However, the use of such standards is inappropriate for native population of the UAE because of the high prevalence of thalassemia. In Emiratis, the overall prevalence of $\beta$-thalassemia trait is $9 \%$ to $20 \%$; it varies in 
TABLE 1. Laboratory investigation of the family.

\begin{tabular}{|c|c|c|c|c|c|c|c|c|c|c|c|}
\hline & $\begin{array}{l}\text { Age } \\
(\mathrm{y})\end{array}$ & $\begin{array}{c}\mathrm{RBC} \\
\left(\mathrm{x} 10^{12} / \mathrm{L}\right) \\
\end{array}$ & $\begin{array}{l}\text { Reticulocy } \\
\text { te }\left(\times 10^{9} / \mathrm{L}\right)\end{array}$ & $\begin{array}{c}\mathrm{Hb} \\
(\mathrm{g} / \mathrm{L}) \\
\end{array}$ & $\begin{array}{l}\mathrm{MCV} \\
(\mathrm{fL})\end{array}$ & $\begin{array}{c}\text { RDW } \\
(\%)\end{array}$ & $\begin{array}{c}\text { Ferritin } \\
(\mu \mathrm{g} / \mathrm{L})\end{array}$ & $\begin{array}{c}\mathrm{Hb} \mathrm{A} \\
(\%)\end{array}$ & $\begin{array}{c}\mathrm{Hb} \text { A2 } \\
(\%)\end{array}$ & $\begin{array}{c}\mathrm{Hb} \mathrm{F} \\
(\%)\end{array}$ & $\alpha$-Thalassemia genotype \\
\hline Father & 44 & 5.0 & 72.6 & 127 & 78.4 & 13.4 & 65 & 97.9 & 1.8 & 0.3 & Monoallelic c. ${ }^{*} 92 \mathrm{~A}>\mathrm{G}$ \\
\hline Mother & 43 & 4.7 & 80.5 & 93 & 63.3 & 17.3 & 8 & 97.1 & 2.6 & 0.3 & Biallelic $-\alpha^{3.7} /-\alpha^{3.7}$ \\
\hline Son & 20 & 7.0 & 57.4 & 128 & 57.1 & 18.7 & 59 & 97.8 & 1.8 & 0.4 & Biallelic c. $* 92 \mathrm{~A}>\mathrm{G} /-\alpha^{3.7}$ \\
\hline Son & 20 & 6.4 & 83.4 & 120 & 59.3 & 16.0 & 100 & 96.9 & 2.7 & 0.4 & Biallelic c. $* 92 \mathrm{~A}>\mathrm{G} /-\alpha^{3.7}$ \\
\hline Son & 18 & 4.9 & 91.2 & 129 & 80.4 & 11.9 & 114 & 97.8 & 2.0 & 0.2 & Monoallelic $-\alpha^{3.7}$ \\
\hline Daughter & 13 & 5.0 & 84.3 & 94 & 59.5 & 15.5 & 33 & 97.3 & 1.8 & 0.9 & Biallelic c. $* 92 \mathrm{~A}>\mathrm{G} /-\alpha^{3.7}$ \\
\hline Daughter & 6 & 5.4 & 83.9 & 99 & 57.2 & 17.2 & 55 & 97.6 & 1.8 & 0.6 & Biallelic c. $* 92 \mathrm{~A}>\mathrm{G} /-\alpha^{3.7}$ \\
\hline
\end{tabular}

kinships (tribes) from $0 \%$ to $30 \%$ [11-13]. In a study from Dubai, UAE, half of newborns carried at least one variant or deletion in $\alpha$-gene region [14]. Similarly, local studies show the overall prevalence of $\beta$-thalassemia trait is $2 \%$ to $4.5 \%$, and its prevalence between tribes varies from $0 \%$ to $13 \%[5,15]$. The tribal allegiance of an individual is defined by family name from which a physician should be able to estimate the likelihood of thalassemia. In population studies, however, family name is considered 'private' and is unenviable to physicians $[12,15]$. Thus, the large tribal heterogeneity of the frequency of $\alpha$ - and $\beta$ thalassemia imposes uncertainty in the management of individual patients.

The hemoglobin level in apparently healthy Emirati women with $\alpha$-thalassemia trait is between 106 and $142 \mathrm{~g} / \mathrm{L}$, and in Emirati men 128 and $164 \mathrm{~g} / \mathrm{L}$ [12]. The diagnosis of $\alpha$ - and $\beta$-thalassemia trait is based on the presence of: 1) Normal or mildly decreased hemoglobin and low MCV in the absence of iron deficiency, and 2) Normal hemoglobin A2 in $\alpha$-thalassemia trait and elevated hemoglobin A2 in $\beta$ thalassemia trait [16]. Iron deficiency anemia and latent iron deficiency are common among Emirati women (16\% and $26 \%$, respectively) [3]. Therefore, by using locally developed reference standards, six of seven studied family members (all, but the 18-year-old son) have lower hemoglobin than could be explained by $\alpha$ - and $\beta$ thalassemia trait in the population (Table 1). Consequently, the analysis of HBB and HBA was justified.

\section{B. Was HBB analysis really justified?}

The risk of thalassemia major is increased when both parents are $\beta$-thalassemia carriers, which was excluded in the studied couple with their normal hemoglobin A2 (Table 1). This risk assessment, however, is challenged by three related covets. First is the iron deficiency in the mother, which could lower her hemoglobin A2 and mask $\beta$ thalassemia trait $[17,18]$. This possibility could be eliminated by repeating hemoglobin analysis after the correction of iron deficiency. Second is the fact that silent $\beta$-globin gene variants (associated with normal hemoglobin A2) might be more common than appreciated. In Emiratis, heterogeneity of $\beta$-globin variants is high and the frequency of silent $\beta$-thalassemia carriers is not well established [19]. In one Emirati study, the estimated frequency of such variant was $0.9 \%$ and it was suspected in an additional $5 \%$ of subjects but not confirmed [5]. The mechanisms involved in the production of silent carriers are the $\beta$-globin gene mutation/deletion and their interactions with co-inherited $\alpha$ globin gene variants, as well as some non-globin genes [20].
For example, triple or quadruple $\alpha$-globin gene rearrangement, which is also documented in the UAE, increases the imbalance of $\alpha / \beta$ globin-chain production, producing intermediate anemia and normal hemoglobin A2 $[7,11,16]$; the latter two are not unlike those in some of the members of our family. Indeed, this risk is increased in any populations with a high frequency of $\alpha$-thalassemia [16].

The analysis of HBB could have detected only 22 most common mutation. Thus, the negative result does not exclude the presence of other variants, which could be detected with gene sequencing. In our family, the cost/benefit analysis tilted decision against the conduct of this test.

\section{Were HBA1 and HBA2 analyses justified?}

The sequencing of HBA region disclosed the presence of NM_0005176 (HBA2):c.*92A $>$ G and NM_000517.4 (HBA2):c.[-2_-3delAC;-alpha3.7] in father and mother, respectively (Table 1). They are first cousins and the odds of having identical by common descent autosomal allele (coefficient of relatedness) at HBA2 locus is $12.5 \%$. In the UAE, $\alpha^{3.7}$ is one of the most common deletion, while c. ${ }^{*} 92 \mathrm{~A}>\mathrm{G}$ is relatively rare $[11,14]$. The mother is $\alpha^{3.7}$ homozygote; her hemoglobin is lower than expected due to iron deficiency. An 18-year-old son is $\alpha^{3.7}$ heterozygote and his hemoglobin and MCV values are as those in $\alpha$ thalassemia silent carriers. The c. ${ }^{*} 92 \mathrm{~A}>\mathrm{G}$ variant is associated with strong suppression of $\alpha$-globin chain production which, in homozygotes, could produces hemoglobin $\mathrm{H}$ disease, and the genotypes were previously documented in UAE population [ 6-9, 11, 21]. Four children who are double heterozygotes $\left(\alpha^{3.7} /\right.$ c. $\left.{ }^{* 92} \mathrm{~A}>\mathrm{G}\right)$ have lower hemoglobin than expected in $\alpha$-thalassemia trait, and this is due to the mentioned effect of HBA2:c.*92A $>\mathrm{G}$ on HBA1 expression. Hemoglobin A2 is lower in all family members with HBA2:c. $* 92 A>G$ (Table 1). The decrease of hemoglobin $\mathrm{A} 2$ in carrier of $\beta$-thalassemia gene could produce silent $\beta$-thalassemia, which justifies analysis of $\mathrm{HBB}$ in the parents with a normal hemoglobin A2 value.

\section{CONCLUSION}

The use of common 'reference standards' for erythrocyte parameters in Emirati population, which has high frequency of thalassemia, is not always suitable. In this population, the use of reference standards for thalassemia trait, developed locally, are shown to be helpful. At the same time, epidemiologic and genetic studies in the local population have expended knowledge about of thalassemia and, paradoxically, increased uncertainty of the diagnosis in individual patients. This uncertainty breeds additional investigations. Here, genetic tests explained the anemia in 
this family, excluded hemoglobin $\mathrm{H}$ disease, and reduced the risk of $\beta$-thalassemia major and hemoglobin $\mathrm{H}$ disease in offspring. Our analysis show that the rapid socioeconomic development in UAE expends medical knowledge which, unexpectedly, increased diagnostic uncertainty and cost of healthcare.

\section{REFERENCES}

[1] Central Intelligence Agency. The CIA World Factbook 2018-2019, Skyhorse Publishing Co, Washington, DC, 2018.

[2] Abdel Majid L, Abu-Khalid FA, Al-Amin MH, Al-Azmeh A, AlBanna S. Arab Human Development Report 2003. Building a Knowledge Society. United Nations Development Program, Regional Bureau for Arab States (RBAS), New York, 10017, 2003.

[3] Al-Dabbagh B, Shawqi S, Yasin J, Al Essa A, Nagelkerke N, Denic S. Half of the Emirati population has abnormal red cell parameters: challenges for standards and screening guidelines. Hemoglobin, vol. 38(1), pp. 56-9, 2014.

[4] Al-Gazali L, Hamamy H, Al-Arrayad S. Genetic disorders in the Arab world. British Medical Journal, vol. 333(7573), pp. 831-834, Oct 2006.

[5] Belhoul KM, Abdulrahman M, Alraei RF. Hemoglobinopathy carrier prevalence in the United Arab Emirates: first analysis of the Dubai Health Authority premarital screening program results. Hemoglobin, vol. 37(4), pp. 359-368, 2013.

[6] Karbassi I, Maston GA, Love A, DiVincenzo C, Braastad CD, Elzinga CD, Bright AR, Previte D, Zhang K, Rowland CM, McCarthy M, Lapierre JL, Dubois F, Medeiros KA, Batish SD, Jones J, Liaquat K, Hoffman CA, Jaremko M, Wang Z, Sun W, Buller-Burckle A, Strom CM, Keiles SB, Higgins JJ. A Standardized DNA Variant Scoring System for Pathogenicity Assessments in Mendelian Disorders. Human Mutation, vol. 37, pp. 127-134, 2016.

[7] Yüregir GT, Aksoy K, Cürük MA, Dikmen N, Fei YJ, Baysal E, Huisman $\mathrm{TH} . \mathrm{Hb} \mathrm{H}$ disease in a Turkish family resulting from the interaction of a deletional alpha-thalassaemia-1 and a newly discovered poly A mutation. British Journal of Haematology, vol. 80, pp. 527-532, 1992.

[8] Harteveld LC, Higgs RD. $\alpha$-Thalassaemia. Orphanet Journal of Rare Diseases, vol. 5, pp. 13, 2010.

[9] Rajab A, Hamza N, Al Harasi S, Al Lawati F, Gibbons U, Al Alawi I, Kobus K, Hassan S, Mahir G, Al Salmi Q, Mons B, Robinson P. Repository of mutations from Oman: The entry point to a national mutation database. F1000Research, vol. 23(4), pp. 891, Sep 2015.

[10] Viprakasit V, Ayyub H, May A. Dinucleotide deletion in -alpha3.7 allele causes a severe form of alpha+ thalassaemia. European Journal of Haematology, vol. 71, pp. 133-136, 2003.

[11] Baysal E. $\alpha$-Thalassemia syndromes in the United Arab Emirates. Hemoglobin, vol. 35, pp. 574-580, 2011.

[12] Denic S, Souid AK, Nagelkerke N, Showqi S, Balhaj G. Erythrocyte reference values in Emirati people with and without $\alpha+$ thalassemia. BMC Blood Disorders, vol. 11, pp. 1, Feb 2011.

[13] Mekaini LA, Denic S, Jabri ON, Narchi H, Souid AK, Al-Hammadi S. Red cell parameters in infant and children from the Arabian Peninsula. Am J Blood Res. 2015 Dec 25;5(2):101-7.

[14] El-Kalla S, Baysal E. $\alpha$-Thalassemia in the United Arab Emirates. Acta Haematologica, vol. 100(1), pp. 49-53, 1998.

[15] Denic S, Aden B, Nagelkerke N, Essa AA. $\beta$-Thalassemia in Abu Dhabi: consanguinity and tribal stratification are major factors explaining the high prevalence of the disease. Hemoglobin, vol. 37(4), pp. 351-358, 2013.

[16] Origa R, Moi P. Alpha-Thalassemia. 2005 Nov 1 [updated 2016 Dec 29]. In: Adam MP, Ardinger HH, Pagon RA, Wallace SE, Bean LJH, Stephens K, Amemiya A, editors. GeneReviews ${ }^{\circledR}$ [Internet]. Seattle (WA), University of Washington, Seattle; 1993-2020. Available from http://www.ncbi.nlm.nih.gov/books/NBK1435/.

[17] Denic S, Agarwal MM, Al Dabbagh B, El Essa A, Takala M, Showqi S, Yassin J. Hemoglobin A2 Lowered by Iron Deficiency and $\alpha$ Thalassemia: Should Screening Recommendation for $\beta$-Thalassemia Change? ISRN Hematology, vol. 2013, pp. 858294, 2013.

[18] 18. Sharma P, Das R, Trehan A, Bansal D, Chhabra S, Kaur J, Marwaha RK, Varma N, Garewal G. Impact of iron deficiency on hemoglobin $\mathrm{A} 2 \%$ in obligate $\beta$-thalassemia heterozygotes. International Journal of Laboratory Hematology, vol. 37(1), pp. 10511, Feb 2015.
[19] Baysal E. Molecular heterogeneity of beta-thalassemia in the United Arab Emirates. Community Genetics, vol. 8(1), pp. 35-39, 2005.

[20] Cao A, Galanello R. Beta-thalassemia. Genetic Medicine, vol. 12(2), pp. 61-76, Feb 2010.

[21] Galanello R, Cao A. Gene test review. Alpha-thalassemia. Genetic Medicine, vol. 13(2), pp. 83-8, Feb 2011. 